\title{
Diversity of marsupial frogs (Anura: Hemiphractidae: Gastrotheca) in the northern Cordillera Central, Peru, with the descriptions of two new species
}

\author{
William E. Duellman ${ }^{1}$ and Pablo J. Venegas ${ }^{2}$ \\ ${ }^{1}$ Biodiversity Institute, University of Kansas, 1345 Jayhawk Blvd, Lawrence, Kansas 66045-7561, USA. E-mail: duellman@ \\ ku.edu. \\ ${ }^{2}$ División de Herpetología, Centro de Ornithología y Biodiversidad, Santa Rita N 105, Of. 202, Urb. Huertos de San Antonio, \\ Surco, Lima, Peru. E-mail: sancarranca@yahoo.es.
}

\begin{abstract}
Diversity of marsupial frogs (Anura: Hemiphractidae: Gastrotheca) in the northern Cordillera Central, Peru, with the descriptions of two new species. Two new species of Gastrotheca are represented by adult females, genomic data of these are included in a phylogenetic analysis, whereby they are placed in the northern clade of the subgenus Gastrotheca. One new species, G. spectabilis, is unique within the genus in having a color pattern consisting of white labial, rostral, and canthal stripes. The second new species, $G$. oresbios, has a dorsal color pattern of dark paravertebral markings and canthal stripe, but no pale labial stripe; thus it resembles G. abdita, which differs by having an inner tarsal fold, a wider interorbital distance, and smooth skin on the dorsum lacking scattered tubercles as in G. oresbios. Of the nine species of Gastrotheca in the northern Cordillera Central, only G. spectabilis, G. ossilaginis, and G. oresbios lack an inner tarsal fold. The third species is represented by two juveniles; it is briefly described but not named. Of the nine species of Gastrotheca known from the high elevations in the northern part of the Cordillera Central in northern Peru, only two are members of the subgenus Duellmania that occurs principally north of the Huancabamba Depression. Only one of the nine species of species of Gastrotheca in the northern part of the Cordillera Central is shared with the Cordillera Occidental in Peru, and none of the species is shared with the Ecuadorian ranges of the Andes.
\end{abstract}

Keywords: Andes, Huancabamba Depression, new species, northern Peru, subgenus Gastrotheca, southern Ecuador.

Received 29 August 2016

Accepted 30 November 2016

Distributed December 2016 


\begin{abstract}
Resumen
Diversidad de ranas marsupiales (Anura: Hemiphractidae: Gastrotheca) en el norte de la Cordillera Central de Peru, con las descripciones de dos nuevas especies. Dos especies nuevas de Gastrotheca se encuentran representadas por hembras adultas, datos genómicos de ambas especies en un análisis filogenético sitúan a estas en el clado norteño del subgénero Gastrotheca. Una de las nuevas especies, G. spectabilis, es la única en el género con una raya pálida labial, rostral y cantal. La segunda nueva especie, G. oresbios, tiene un patrón de coloración dorsal de marcas paravertebrales y raya cantal, pero no una raya labial pálida. Esta semeja a G. abdita, de cual se diferencia por tener pliegue tarsal interno, mayor distancia interorbital y piel lisa en el dorso, sin tubérculos dispersos, como en G. oresbios. De las nueve especies de Gastrotheca que ocurren en el norte de la Cordillera Central, solo G. spectabilis, G. ossilaginis, y G. oresbios carecen del pliegue tarsal interno. La tercera especie esta representada por dos especímenes juveniles y es brevemente descrita más no nombrada. De las nueve especies de Gastrotheca conocidas para las zonas altas de la porción norte de la Cordillera Central en el norte de Perú, solo dos especies son miembros del género Duellmania, que ocurre principalmente al norte de la Depresión de Huancabamba. Solo una, de estas nueve especies de la Cordillera Central, es compartida con la Cordillera Occidental de Perú y ninguna especie se comparte con los Andes de Ecuador.
\end{abstract}

Palabras claves: Andes, Depresión de Huancabamba, especies nuevas, norte de Peru, subgénero Gastrotheca, sur de Ecuador.

\begin{abstract}
Resumo
Diversidade de pererecas-marsupiais (Anura: Hemiphractidae: Gastrotheca) no norte da Cordilheira Central, Peru, com descrições de duas novas espécies. Duas novas espécies de Gastrotheca são representadas por fêmeas adultas, seus dados genômicos estão incluídos em uma análise filogenética, em que são colocadas no clado do norte do subgênero. Uma nova espécie, $G$. spectabilis, é única no gênero por apresentar um padrão de coloração consistindo de faixas labial, rostral e cantal brancas. A segunda nova espécie, G. oresbios, possui um padrão de coloração dorsal com marcas paravertebrais e faixa cantal escuras, mas sem faixa labial clara; assim, assemelha-se a G. abdita, que difere pela posse de uma dobra tarsal interna, maior distância interorbital e pele lisa do dorso desprovida de tubérculos dispersos como em G. oresbios. Das nove espécies de Gastrotheca do norte da Cordilheira, apenas G. spectabilis, G. ossilaginis e G. oresbios não possuem uma dobra tarsal interna. A terceira espécie é representada por dois juvenis; essa espécie é descrita brevemente, mas não nomeada. Das nove espécies de Gastrotheca conhecidas de grandes altitudes da porção norte da Cordilheira Central do norte do Peru, apenas duas pertencem ao subgênero Duellmania, que ocorre principalmente ao norte da Depressão de Huancabamba. Apenas uma das nove espécies de Gastrotheca da porção norte da Cordilheira Central é compartilhada com a Cordilheira Ocidental do Peru, e nenhuma é compartilhada com as serras equatorianas dos Andes.
\end{abstract}

Palavras-chave: Andes, Depressão de Huancabamba, espécie nova, norte do Peru, subgênero Gastrotheca, sul do Equador.

\section{Introduction}

Frogs in the family Hemiphractidae are unique in that fertilized eggs are carried on the back of the female (Cryptobatrachus, Hemiphractus, and Stefania), in an open pouch on the back of the female (Fritziana), or in a closed pouch on the back of the female (Flectonotus and Gastrotheca). Molecular phylogenetic analyses place Gastrotheca as the most derived genus in the family (Blackburn and Duellman 2013, Castroviejo-Fisher et al. 2015, Duellman 2015). The greatest diversity of Gastrotheca is in the Andes where the elevational ranges of some species (e.g., G. peruana and G. riobambae) exceed $4000 \mathrm{~m}$. Within this array of montane 
frogs, some species are biphasic (aquatic larval stage) and others have direct development (no larval stage)

In their phylogenetic analysis of Gastrotheca Blackburn and Duellman (2013) recognized one major clade as the northern Andean clade and another as a Central Andean clade. Subsequently, Duellman (2015) defined seven subfamilies within Gastrotheca. The formerly recognized northern Andean clade became Duellmania, a subgeneric name proposed by Dubois (1987), whereas the Central Andean clade became the subgenus Gastrotheca. As depicted in Figure 1, the phylogenetic tree of the subgenus Gastrotheca contains three major clades. The northern clade contains species that have a biphasic life cycle; the group ranges from central Ecuador to northern Peru and contains the new species described herein. The Peruvian clade consists of species undergoing direct development and ranging from northern Peru to northern Bolivia. The southern clade is made up of species having both kinds of life histories; species in this clade range from central Peru to northern Argentina.

Recognition of species of marsupial frogs in southern Ecuador and northern Peru began slowly. Boulenger (1900) described the first species, Gastrotheca peruana from the northern part of the Cordillera Occidental in Peru. This was followed by the descriptions of G. monticola from the Huanacabamba Depression in northern Peru (Barbour and Noble 1920) and G. lojana from the Loja Basin in southern Ecuador. Intensive fieldwork by Duellman and his associates revealed the existence of three more species from southern Ecuador, G. psychrophila (Duellman 1974) and G. litonedis and G. pseustes (Duellman and Hillis 1987). Gastrotheca galeata (Trueb and Duellman 1978) and G. lateonota (Duellman and Trueb 1988) were named from the Huancabamba Depression in northern Peru and seven from northern Peru-G. abdita (Duellman 1987), G. ossilaginis and G. phalarosa (Duellman and Venegas 2005), G. phelloderma (Lehr and Catenazzi 2011), G. dysprosita (Duellman 2013), and G. aguaruna and G. aratia

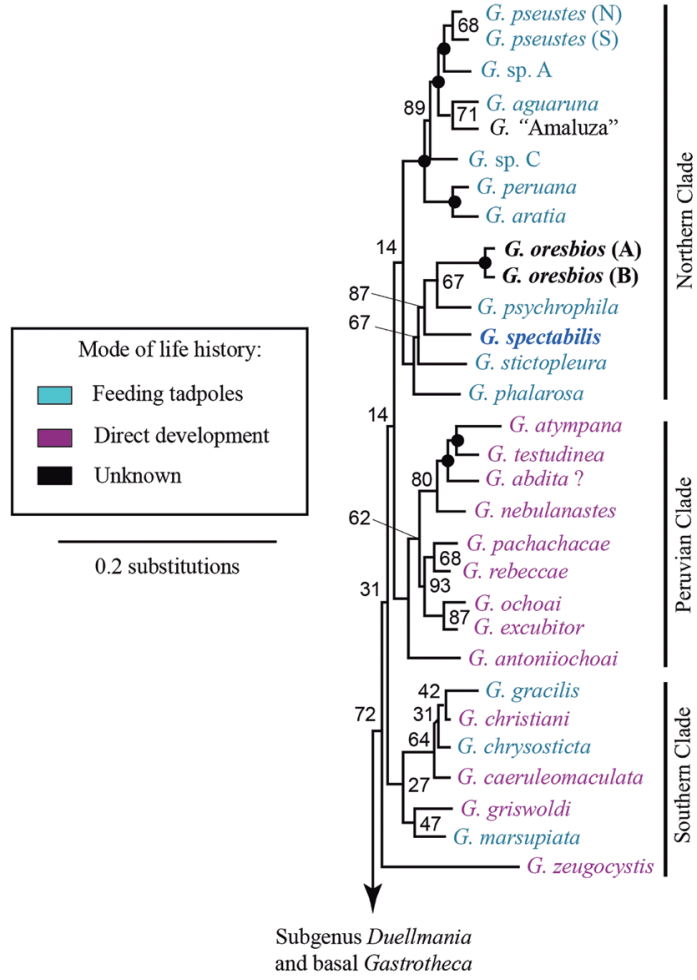

Figure 1. Maximum likelihood phylogeny of species in the subgenus Gastrotheca, modified from Duellman (2015). Names of species described in this paper are in bold face. See text for further explanation.

(Duellman et al. 2014). Most recently, CarvajalEndara et al. (2017) are describing three more species from the Andes in southern Ecuador. To this conglomeration we add two more species from northern Peru. Molecular data of these three species and the two described herein were used in a previous molecular analysis (Duellman 2015).

\section{Materials and Methods}

Eleven specimens of Gastrotheca collected in the northern part of the Cordillera Central in Peru by PJV and studied in detail by WED form 
the basis of this paper. Two new species are contained in this sample. Unfortunately one of these species is represented by only one adult female; the other is represented by an adult female, six subadults, and one juvenile. Two other juveniles probably represent another undescribed species; unfortunately tissues were not taken from these individuals.

The morphological characters and 16 measurements are those used by Duellman and Hillis (1987) and Duellman (2013, 2015) All measurements are in millimeters, and snout-vent length is abbreviated SVL. Specimens examined other than the new species are listed in Appendix I. Codes for museum collections are those listed by Sabaj Pérez (2010). The phylogenetic tree is based on the tree provided by Duellman (2015) constructed from analyses of four genes (16S, ND1, POMC, and RAG-1); see Duellman (2015) for details; Genbank accession numbers are given in Appendix II. In the tree (Figure 1), the two samples of Gastrotheca pseustes are labeled "N" and "S", representing northern and southern populations of that species. Of the two $G$. oresbios sp. nov., "A" is the holotype CORBIDI 11076 from Abra Barro Negro and " $\mathrm{B}$ " is CORBIDI 11040 from Hornillo. The associated Genbank numbers are designated Gastrotheca sp. E for the holotype of G. spectabilis sp. nov. and Gastrotheca sp. F for the holotype of $G$. oresbios sp. nov. (see Figure 3.1 in Duellman 2015).

In the field, elevations and geographic coordinates were obtained by Garmin ${ }^{\circledR}$ GPS using datum WGS 84 .

\section{Results}

The new species are placed in the genus Gastrotheca because females have dorsal brood pouches. Furthermore, genomic data place them in the subgenus Gastrotheca (Figure 1).

Gastrotheca oresbios sp. nov.

Gastrotheca sp. F, Duellman 2015, p. 282, Fig. 12.1.

(Figure 2)
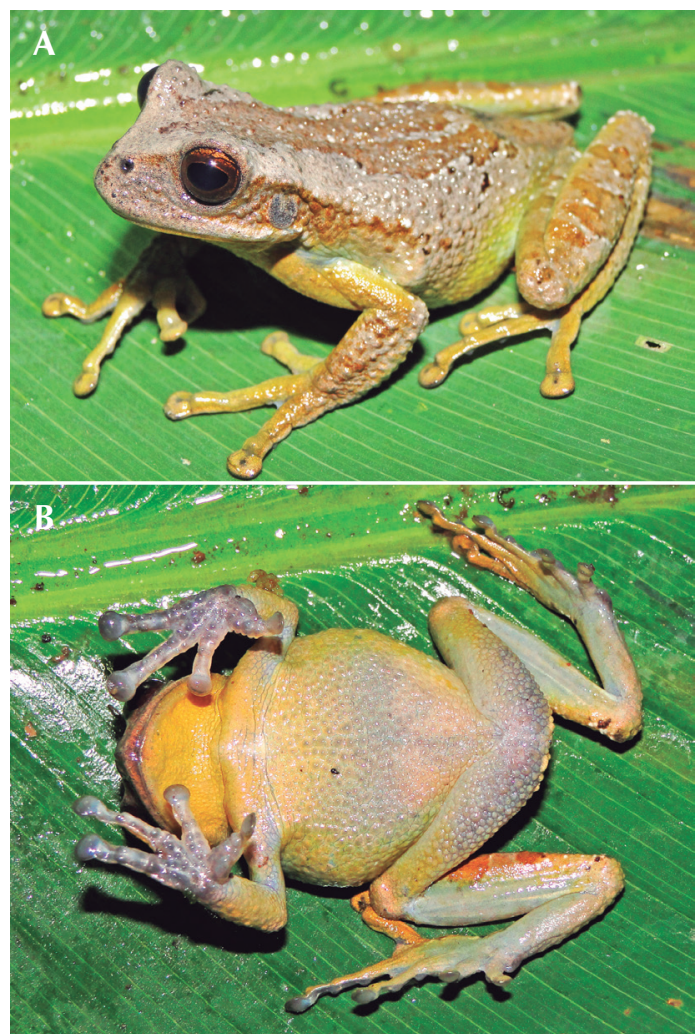

Figure 2. Holotype of Gastrotheca oresbios, CORBIDI 11076, female, $45.7 \mathrm{~mm}$ SVL. Photos by Pablo J. Venegas.

Holotype-CORBIDI 11076, an adult female, from Abra Barro Negro, 642'58.2" S, 7751'53.8" W, 3290 m, Provincia Chachapoyas, Departamento Amazonas, Peru, collected by P. J. Venegas and L. Y. Echevaría on 24 May 2012.

Referred specimen.-CORBIDI 11040, a juvenile, from Quintecocha 6 $51^{\prime} 33^{\prime \prime} \mathrm{S}, 7^{\circ} 42^{\prime} 14.7^{\prime \prime} \mathrm{W}$, 3119 m, Provincia Marical Caceres, Departamento San Martin, Peru, collected by P. J. Venegas and L. Y. Echevaría on 19 May 2012.

Diagnosis.-Adults of this species attain a maximum snout-vent length (SVL) of $45.7 \mathrm{~mm}$; tibia length less than 55\% SVL, slightly longer than foot; interorbital distance about 1.5 times 
width of upper eyelid; skin on the dorsum smooth with scattered tubercles, not co-ossified with skull, lacking transverse ridges. Supraciliary processes and calcars on heels absent; tympanic annulus distinct, granular. Finger I barely shorter than Finger II; discs on fingers much wider than digits proximal to discs; fingers not webbed; outer toes webbed basally. Dorsum brown with darker brown paravertebral marks; markings on head and pale dorsolateral stripe absent; flanks gray with greenish yellow-tan axillary and inguinal regions.

Gastrotheca oresbios has a nearly acuminate snout; five other species in the genus have an acute snout in dorsal view and also occur in the Andes. Of these, G. abdita known only from the Cordillera Colán in northern Peru differs from G. oresbios by having conical ulnar tubercles, an enlarged tubercle on the heel, and an inner tarsal fold on the distal two thirds of the tarsus. Furthermore, in G. abdita Fingers fingers I and II are equal in length, and the tympanum is vertically ovoid. The second species, the smaller G. ochoai (maximum SVL $30.4 \mathrm{~mm}$ in males, $37.5 \mathrm{~mm}$ in females [Duellman 2015]) is a bromeliad inhabitant in the Cordillera Oriental in southern Peru; it differs from the larger $G$. oresbios by having a vertically ovoid tympanum with a smooth annulus. Gastrotheca pacchamama and $G$. rebeccae, inhabitants of the Cordillera Oriental in central Peru, differ from G. oresbios by having a pale labial stripe and a smooth tympanic annulus. Gastrotheca zeugocistis also has a smooth tympanic annulus and paired brood pouches. The six remaining species in the Peruvian Andes that might be confused with $G$. oresbios have bluntly rounded snouts in dorsal view. Of these, G. antoniiochoai has a shagreen tan dorsum with brown and green flecks; furthermore, the interorbital distance is less than $85 \%$ of the eyelid, whereas G. pachachacae has a granular dorsum and tan flanks with brown spots. Gastrotheca nebulanastes differs from $G$. oresbios by having granular skin on the dorsum, a smooth tympanic annulus, and Finger I longer than Finger II. Gastrotheca excubitor and $G$. griswoldi differ from $G$. oresbios by having a smooth tympanic annulus and usually having a pale labial stripe. As the specific name implies, $G$. atympana differs from $G$. oresbios by lacking a tympanum; furthermore the snout is narrowly truncate in dorsal view and the skin on the dorsum is shagreen.

Description of holotype.-Adult female; body robust; SVL $45.7 \mathrm{~mm}$; head slightly wider than long; snout acuminate in dorsal view, rounded in profile; canthus rostralis rounded in section; loreal region concave; lips rounded; top of head flat; interorbital distance $158 \%$ width of upper eyelid; internarial area flat; nostrils not protuberant, directed anterolaterally at point well posterior to anterior margin of lower jaw, below anterior terminus of canthus rostralis; diameter of eye greater than its distance from nostril; tympanum round, its diameter about two thirds that of eye, separated from the eye by distance about 5.5 times length of the tympanum; tympanic membrane smooth, annulus distinct, granular; supratympanic fold moderately heavy, tuberculate, angular in section, extending from posterior corner of orbit to point above insertion of arm, not obscuring tympanum.

Arm robust; ulnar tubercles absent; hand moderately large; fingers unwebbed; discs on fingers round, wider than digit; diameter of the disc on Finger III slightly less than length of tympanum; relative lengths of the fingers I $<$ II $<$ IV < III; subarticular tubercles moderately large, subconical, distal tubercle on Finger II bifid; supernumerary tubercles round, present only on proximal digits; palmar tubercle small, divided; prepollical tubercle large, ovoid, slightly elevated. Hind limbs moderately robust; tibia length 52.3\% SVL; foot length 50.8\% SVL; heel lacking enlarged tubercle; inner tarsal fold and outer metatarsal tubercle absent; inner metatarsal tubercle small, not elevated, ovoid, not visible from above; toes moderately long; relative lengths toes I $<$ II $<$ III $<$ V $<$ IV. Toes I-II not webbed; basal webbing between Toes III and IV and between Toes IV and V; subarticular 
tubercles moderately large, subconical; supernumerary tubercles, small, subconical, present only on proximal segments of toes.

Skin on dorsum smooth with scattered small tubercles, especially numerous on supratympanic fold and on side of head posterior to eye; flanks granular anteriorly, tubercular posteriorly; skin on belly and proximal posteroventral surfaces of thighs granular; cloacal tubercles and folds absent; pair of enlarged tubercles below cloaca; opening of brood pouch U-shaped with anterior border at level of sacrum. Dentigerous processes of vomers posteromedially inclined, narrowly separated medially, between round choanae, each bearing five teeth; tongue cordiform, shallowly notched posteriorly, free behind for about one fourth of its length; nature of vocal slits unknown.

In preservative, dorsal surface of body and limbs dull gray with faintly darker grayish brown paravertebral marks originating on eyelids, extending posteriorly, coalescing at midlength of body, coalescing posterior to sacrum, then bifurcating and terminating at level of opening of brood pouch. Flanks pale gray above cream below; anterior and posterior surfaces of thighs and ventral surfaces of body and limbs dull cream; no transverse bars hind limbs. Markings on head consisting of dark brown canthal and postorbital regions. Axillary and inguinal regions pale greenish tan.

In life, the dorsum is tan with reddish brown middorsal mark on head and body and transverse bars on forearm, thigh, and shank (Figure 2A). Loreal region and side of head reddish brown; this color extending to point above insertion of forelimb. Anterior and posterior surfaces of thighs gray with scattered small black flecks; mid-flanks tan; groin greenish yellow. Belly and ventral surfaces of limbs pale gray; throat yellow; paracloacal tubercles yellow (Figure 2B). Iris dull bronze with fine black reticulations.

Measurements of holotype in $\mathrm{mm}$ are: SVL 45.7, tibia length 23.9, foot length 23.2 , head length 16.1 , head width 17.1 , interorbital distance 7.1, internarial distance 3.3, width of eyelid 4.5, eye-nostril distance 4.1, diameter of eye 4.7, diameter of tympanum 3.5.

Variation.-The juvenile (CORBIDI 11040) has a SVL of $17.3 \mathrm{~mm}$; it is the individual shown as G. oresbios (B) in the phylogenetic tree (Figure 1 ), where the holotype (CORBIDI 11076) is shown as G. oresbios (A). The dorsal pattern of the juvenile is identical to that of the holotype but differs by having the belly with black flecks and the ventral surface of thighs and shanks gray with black marks.

Distribution and ecology.-Gastrotheca oresbios is known only from two localities at elevations of $3290 \mathrm{~m}$ on Abra Barro Negro and at $3119 \mathrm{~m}$ in Quintecocha in the northern part of the Cordillera Central in northern Peru (Figure 3). Gastrotheca dysprosita occurs at elevations of 3370 and $3440 \mathrm{~m}$ on the same slope of Abra Barro Negro (Duellman, 2013) so the two species may occur sympatrically. The holotype of $G$. oresbios was found by day inside a large bromeliad fastened to a rocky outcrop. The general landscape of the type locality consists of extensive pastures for cattle with some scattered rocky outcrops, and small patches of forest from where advertisement calls of Gastrotheca were heard. Only Pristimantis melanogaster is known to be sympatric with $G$. oresbios at the type locality. At Quintecocha the juvenile (CORBIDI 11040) was perched on herbaceous vegetation by day on a trail in a patch of montane forest. Sympatric anurans in this locality were Pristimantis corrugatus and Rhinella arborescandens. Gastrotheca ossilaginis and Telmatobius atahualpai were collected at the same place in November 2003.

Etymology.-The specific name oresbios is a Greek noun meaning living on mountains.

Gastrotheca spectabilis sp. nov. Gastrotheca sp. E, Duellman 1915, p. 282, Fig. 12.1.

(Figure 4) 


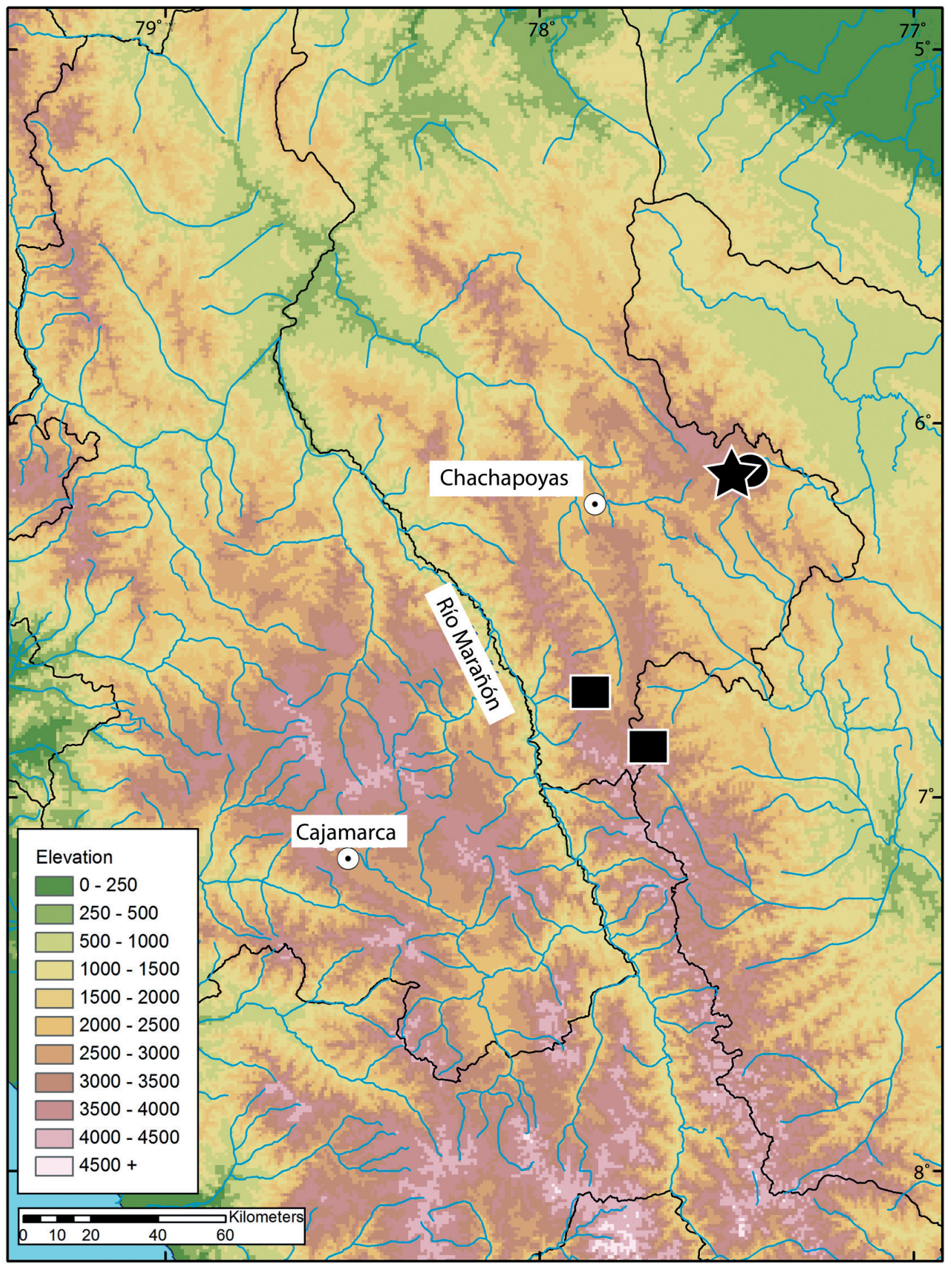

Figure 3. Northern Peru showing localities of known occurrence of three species of Gastrotheca, The square is G. oresbios, star is G. spectabilis, and circle is G. sp. D. 
Holotype.-CORBIDI 11790. Brooding female, from Hornillo, 6³0'05" S, 77²9'04.9" W, 3308 $\mathrm{m}$, Distrito de Vista Alegre, Provincia Rodríguez de Mendoza, Departamento de Amazonas, Peru, obtained by P. J. Venegas and V. Durán on 31 August 2012.

Paratypes.-CORBIDI 11644, 11753, 1178081, and KU 342532, all subadults collected with the holotype.

Diagnosis.-No other Andean species of Gastrotheca has a color pattern like that of $G$. spectabilis; the tan dorsum with irregular brown spots and middorsal mark and a dark brown venter with cream granules are unique within the genus. Three other species of Gastrotheca are known from the vicinity of the type locality of G. spectabilis. Of these, G. phelloderma differs from $G$. spectabilis by having pustular ridges on the dorsum, an interorbital distance equal to the width of the upper eyelid, and an inner tarsal fold extending the entire length of the tarsus, as opposed to smooth skin on the dorsum, an interorbital distance twice the width of the upper eyelid, and no inner tarsal fold in G. spectabilis. The smaller G. oresbios differs from G. spectabilis by having a granular tympanic annulus and by lacking the pale stripes on the head, and $G$. aguaruna differs by having a green dorsum and flanks, an inner tarsal fold on the distal half of the tarsus, and in interorbital distance about equal to the width of the upper eyelid. Of the other species of Gastrotheca in the Andes in northern Peru, G. galeata and G. ossilaginis differ from $G$. spectabilis by having the skin on the head co-ossified with the underlying dermal elements of the skull; furthermore, in G. galeata the head is casqued with flared maxillaries and premaxillaries, and an elevated transverse occipital ridge, and G. ossilaginis differs further by being green and lacking pale stripes on the head. In contrast to G. spectabilis, five other species (G. abdita, aratia, lateonota, monticola, and peruana) in northern Peru have distinct inner tarsal folds; in these species the dorsum is
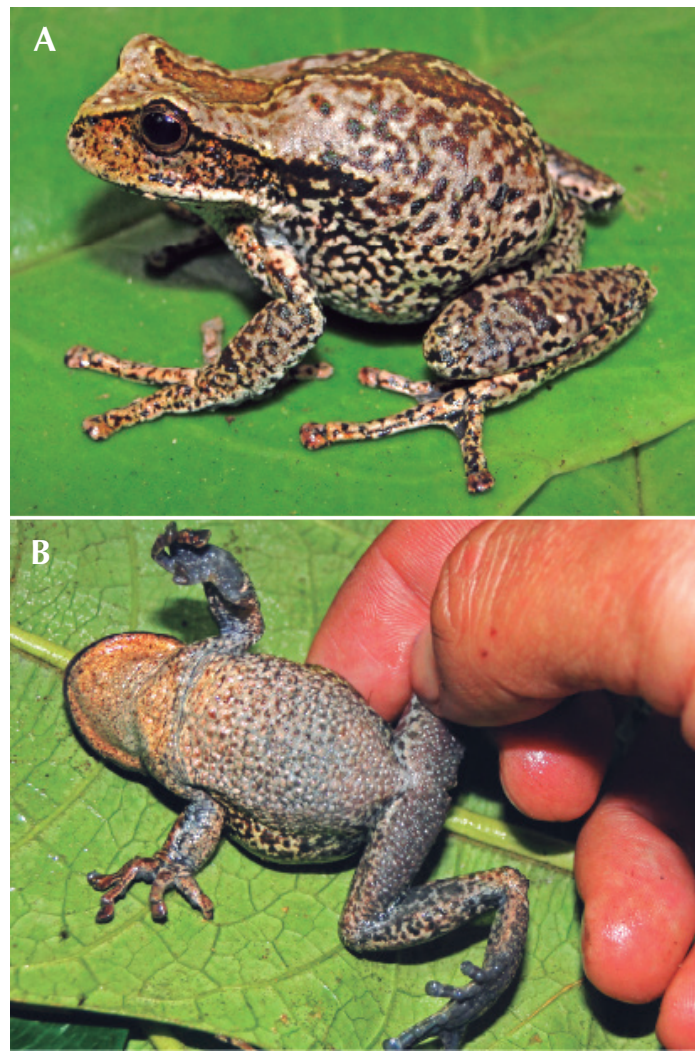

Figure 4. Holotype of Gastrotheca spectabilis, CORBIDI 11790, female, $47.2 \mathrm{~mm}$ SVL. Photos by Pablo J. Venegas.

tan or green with darker paravertebral marks. The only remaining species of Gastrotheca in the northern Cordillera Central, G. phalarosa, differs from $G$. spectabilis by having a black venter with white spots, pustular skin on the dorsum, and an interorbital distance about equal to the width of the upper eyelid.

Description of holotype.-Adult female; body robust; SVL $47.2 \mathrm{~mm}$; head slightly wider than long; snout acutely rounded in dorsal view, bluntly rounded in profile; canthus rostralis angular in section; loreal region barely concave; lips rounded; top of head flat; interorbital distance $196 \%$ width of upper eyelid; internarial 
area slightly elevated; nostrils not protuberant, directed laterally at point slightly posterior to anterior margin of lower jaw, below anterior terminus of canthus rostralis; diameter of eye about equal to its distance from nostril; tympanum round, its diameter about half that of eye, separated from the eye by distance twice length of the tympanum; tympanic membrane and annulus distinct, smooth; supratympanic fold moderately heavy, tuberculate, angular in section, extending from posterior corner of orbit to point above insertion of arm, not obscuring tympanum.

Arm robust; ulnar tubercles absent; hand moderately large; fingers unwebbed; discs on fingers round, only slightly wider than digit; diameter of the disc on third finger less than length of tympanum; relative lengths of the fingers I $=$ II $<$ IV $<$ III; subarticular tubercles moderate in size, rounded, none bifid; supernumerary tubercles absent; palmar tubercle inconspicuous; prepollical tubercle ovoid, elevated. Hind limbs moderately robust; tibia length $48.5 \%$ SVL; foot length $50.8 \%$ SVL; heel lacking enlarged tubercle; inner tarsal fold and outer metatarsal tubercle absent; inner metatarsal tubercle elevated, ovoid, visible from above; toes moderately long; relative lengths of toes I $<$ II $<$ III $<$ V $<$ IV. Toes I-II lacking webbing; basal webbing exists between Toes III and IV and between Toes IV and V; subarticular tubercles small, subconical; supernumerary tubercles, small, rounded, present only on proximal segments of toes.

Skin on dorsum and flanks smooth with minute tubercles on supratympanic fold and on side of head posterior to eye; skin on belly and proximal posteroventral surfaces of thighs granular; cloacal tubercles and folds absent; opening of brood pouch U-shaped with anterior border at level of sacrum. Dentigerous processes of vomers posteromedially inclined, narrowly separated medially, between round choanae, bearing six and seven teeth; tongue cordiform, shallowly notched posteriorly, free behind for about one fourth of its length; nature of vocal slits unknown.
In preservative, dorsum dull grayish brown with brown middorsal mark narrowly outlined with black; middorsal mark originating on eyelids, extending posteriorly, bifurcating at midlength of body, coalescing posterior to sacrum, terminating at opening of brood pouch. Many irregularly shaped, dark brown spots lateral to midorsal mark; flanks pale gray with many irregularly shaped black spots; narrow dark brown transverse bars on hind limbs-four on thigh, three on shanks, two on foot; those on thighs extending onto posterior surfaces; ventral surfaces of body and limbs dull gray. Markings on head consisting of distinct grayish white labial stripe continuous with narrow rostral stripe bifurcating into narrow canthal stripe extending onto edge of eyelid; loreal region and side of head posterior to eye dark brown.

In life, dorsum of head and body tan (Figure 4A). The broad middorsal mark on the body is reddish brown; it is narrowly outlined with black, which in turn is bordered by creamy tan. Lateral to the middorsal mark are irregular dark brown spots; on the dull cream flanks these spots become smaller and black. The dorsal surfaces of the limbs are dull brown with darker brown irregular spots and on the hind limbs one transverse bar on the thigh and another on the shank. The posterior surfaces of the thighs are dark brown with cream granules. The loreal and tympanic regions on the head are reddish brown with small black flecks. The diffuse labial stripe and narrow rostral and canthal stripes are dull cream. The throat is dull grayish brown; the belly and distal ventral surfaces of the thighs are dark brown with cream granules, whereas the proximal surfaces of the thighs are gray (Figure 4B). The iris is brown with orange flecks.

Measurements of holotype (in $\mathrm{mm}$ ) are: SVL 47.2, tibia length 22.9, foot length 24.0, head length 16.2, head width 17.7, interorbital distance 8.0, internarial distance 3.9, width of eyelid 4.1, eye-nostril distance 5.6, diameter of eye 5.4, diameter of tympanum 3.0. 
Variation.-The five subadult paratypes have SVLs of $22.3-34.2(\bar{x}=28.9) \mathrm{mm}$. They are like the holotype in structural features and coloration.

\section{Distribution and ecology.-Gastrotheca spectabilis} is known only from type locality at an elevation of $3308 \mathrm{~m}$ in northern Departamento de Amazonas, Peru (Figure 3). The holotype was collected at night walking on moss near the edge of a patch of montane forest on a slope covered by páramo. The subadult paratypes were collected by day inside bromeliads $2-4 \mathrm{~m}$ above the ground in the same patch of montane forest. No other anurans were found in the same patch of forest; however, several individuals of Pristimantis sp., G. aguaruna, and G. phalarosa were collected at the surrounding páramo.

Etymology.-The specific name spectabilis is a Latin adjective meaning showy. The name refers to the unusual dorsal color pattern.

\section{Unnamed Species Gastrotheca species D.} (Figure 5)

This species is represented by two small juveniles, CORBIDI 11664-65, having SVLs of 15.5 and $16.8 \mathrm{~mm}$, respectively. Both were collected in Quebrada Salas, 2575 m, Distrito Vista Alegre, Provincia Rodríguez de Mendosa, Departamento Amazonas, Peru (Figure 3). Both specimens were collected by night $(21: 00 \mathrm{~h})$ on leaves $1.5 \mathrm{~m}$ above the ground near a trail in primary montane forest. Sympatric anurans were Hypodactylus sp., Pristimantis corrugatus, $P$. schultei, and $P$. sp. Advertisement calls of Gastrotheca were heard from the canopy of forest at the same place.

The skin on the dorsum is smooth with a few minute tubercles. The dorsum is pale brown with slightly darker markings consisting of an interorbital bar connected to paravertebral marks that extend to the sacrum and transverse bars on the thigh and two on the shank (Figure 5A). The belly is dark grayish brown. The distinguishing color markings are a black inguinal region with
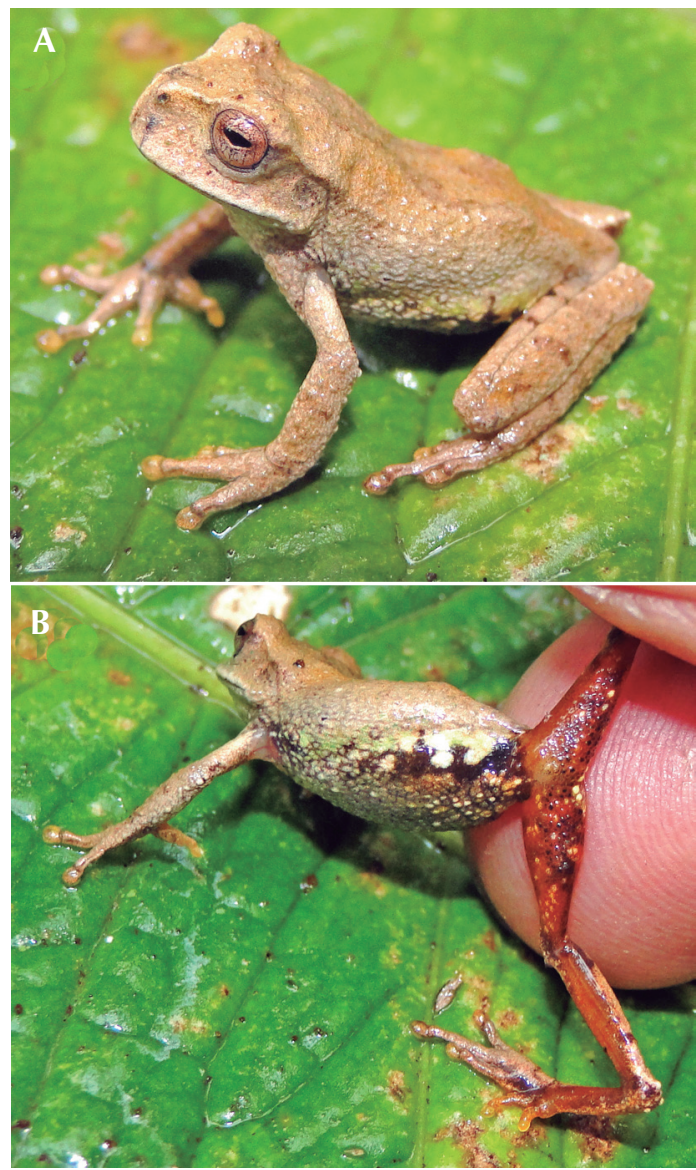

Figure 5. Juvenile of Gastrotheca species D, CORBIDI 11655, $16.8 \mathrm{~mm}$ SVL. Photos by Pablo J. Venegas.

large cream spots and dull red anterior and ventral surfaces of the thigh and shank (Figure $5 \mathrm{~B})$. The iris is dull bronze with fine black reticulations.

\section{Discussion}

The South American tectonic plate separated from Africa in the Early to Middle Cretaceous and arced northwestward to encounter the Nazca Plate, the subduction of which was largely responsible for the orogenic events resulting in 
the rise of the Andes. There is a major structural deflection of the Andes in what is now southern Ecuador and northern Peru; this is the Huancabamba Deflection, physiographically referred to as the Huancabamba Depression. Significant differences exist in the origins of the Andes north of the depression and those to the south of the depression (Gregory-Wodzicki 2000). As summarized by Duellman (1999), the Huancabamba Depression is a complex system of relatively low mountain ranges separated by low basins. In the depression the major cordilleras of the Ecuadorian Andes and the Peruvian Andes terminate or are fragmented into isolated ranges usually no more than $3500 \mathrm{~m}$ high and separated by valleys mostly between 1000 and $2000 \mathrm{~m}$ above sea level. The Cordillera Colán is one of those isolated highlands with crests above $3500 \mathrm{~m}$. Within the depression, the valleys mostly are covered with dry scrub forest consisting mainly of legumes and cacti. Dramatically different vegetation is found on windward and leeward slopes of north-south mountain ranges, such as the Cordillera de Huancabamba. On the leeward slopes of this range, scrub forest extends nearly to $3000 \mathrm{~m}$. On the windward slopes scrub forest extends to about $1700 \mathrm{~m}$, above which humid mountain forest prevails to about $3000 \mathrm{~m}$; above this elevation there is elfin forest with dwarfed trees, a great amount of moss, and many terrestrial and arboreal bromeliads (Duellman and Wild 1993). Elevations above $3000 \mathrm{~m}$ in the northern Cordillera Central are characterized by regions of grassland (puna); the puna dominated by bunch grass (Stipa) with small bushes (principally Baccharis) and terrestrial bromeliads and with deep mosses in some places.

Frogs of the genus Gastrotheca in the high Andes (mostly above $2500 \mathrm{~m}$ ) make up the subgenera Duellmania (14 species) and Gastrotheca (36 species including two unnamed ones). The distributions of these 50 species range from northern Colombia to northwestern Argentina. The enigmatic Gastrotheca galeata in the Huancabamba Depression was placed in its own subgenus, Edaphotheca, by Duellman (2015). No species of high-Andean Gastrotheca cross the Huancabamba Depression. Two other species, G. testudinea and G. weinlandii, occur at elevations mostly below $2500 \mathrm{~m}$ in the cloud forests on the eastern slopes of the Cordillera Oriental in Ecuador and the Cordillera Central in Peru. The new species from southern Ecuador and northern Peru necessitate a revision of the patterns of distribution of Gastrotheca provided by Duellman and Venegas (2005).

We now recognize eight species of Gastrotheca in southern Ecuador; of these, five occur in the southern Cordillera Oriental; of the 14 species recorded from northern Peru, nine occur in the northern Cordillera Central (Table 1). Among the Ecuadorian species, G. pseustes and $G$. sp. C inhabit páramo; the former descends into subparamo and montane forests. Gastrotheca psychrophila inhabits terrestrial bromeliads in subpáramo; the single specimen of Gastrotheca "Amaluza" was found in humid montane forest. The other species ( $G$. sp. A, G. sp. B, $G$. litonedis, $G$. lojana) have restricted distributions in Andean shrub and montane forests; $G$. sp. A also inhabits pasturelands, and $G$. lojana frequents agaves in dry farmland (CarvajalEndara et al. 2017). Of the Ecuadorian species, G. pyschrophila, G. sp. C, and "Amalusa" are not sympatric with any other species of the genus. However, G. psychrophila and "Amalusa" are known from single localities, and $G$. sp. C is known from only two localities. In contrast, the widely distributed $G$. pseustes is sympatric with $G$. sp. A and G. lojana throughout most of their ranges and also occurs sympatrically with $G$. litonedis and G. sp. B (Carval-Endara et al., 2017).

Three species of Gastrotheca are known from the low to moderate elevations in the Huancabamba Depression, where G. galeata and $G$. lateonota are endemic but allopatric. The third species, G. monticola, also inhabits the extreme northern part of the Cordillera Occidental and the northern part of the Cordillera Central. Two species, G. aratia and G. peruana occur only in the Cordillera Occidental, and $G$. 
Table 1. Distribution of Gastrotheca in the Andes of Southern Ecuador and Northern Peru.

\begin{tabular}{|c|c|c|}
\hline Species & Elevation $(\mathrm{m})$ & Distribution \\
\hline \multicolumn{3}{|r|}{ ECUADOR } \\
\hline G. species A & $2407-3172$ & Southern Cordillera Occidental and southern Cordillera Oriental \\
\hline G. "Amaluza" & 2002 & Southern Cordillera Oriental \\
\hline G. species B & $2177-3018$ & Loja Basin and surrounding slopes \\
\hline G. litonedis & $2750-2854$ & Eastern slopes of southern Cordillera Occidental \\
\hline G. lojana & $1682-3018$ & Andean Basins in provincias Azuay, El Oro, and Loja \\
\hline G. pseustes & $2200-4080$ & Southern Cordillera Occidental and southern Cordillera Oriental \\
\hline G. psychrophila & $1750-2850$ & Southern Cordillera Oriental \\
\hline G. species C & $3205-3406$ & Southern Cordillera Oriental \\
\hline \multicolumn{3}{|r|}{ PERU } \\
\hline G. abdita & 2970-3330 & Cordillera Colán \\
\hline G. aguaruna & $2360-3308$ & Northern Cordillera Central \\
\hline G. aratia & 2560-2875 & Northern Cordillera Occidental \\
\hline G. dysprosita & $3320-3440$ & Northern Cordillera Central \\
\hline G. galeata & $1720-2130$ & Huancabamba Depression \\
\hline G. lateonota & 2770 & Huancabamba Depression \\
\hline G. monticola & $2800-3480$ & $\begin{array}{c}\text { Huancabamba Depression and northern Cordillera Occidental and } \\
\text { northern Cordillera Central }\end{array}$ \\
\hline G. oresbios & 3290-3308 & Northern Cordillera Central \\
\hline G. ossilaginis & $3000-3100$ & Northern Cordillera Central \\
\hline G. peruana & $2200-3520$ & Cordillera Occidental \\
\hline G. phalarosa & 3119-3435 & Northern Cordillera Central \\
\hline G. phelloderma & $3308-3400$ & Northern Cordillera Central \\
\hline G. spectabilis & 3308 & Northern Cordillera Central \\
\hline G. species D & 2575 & Northern Cordillera Central \\
\hline
\end{tabular}

abdita is endemic to the Cordillera Cólan in the Huancabamba Depression. Eight species are endemic to elevations of $2360-3435 \mathrm{~m}$ in the Cordillera Central. None of the species of Gastrotheca in the high Andes in Ecuador and Peru cross the Huancabamba Depression, which obviously is a barrier to latitudinal dispersal in the Andes. However, one species (G. pseustes) of the southern subgenus Gastrotheca occurs in Ecuador south of the equator, and two species (G. dysprosita and G. monticola) of the northern subgenus Duellmania are known only from northern Peru. According to the timetree in Duellman (2015), the two subgenera split in the 
mid-Miocene, a time when the Andes were lower than they are now (Gregory-Wodzicki, 2000), whereas the species in both subgenera differentiated from one another in the mid-Late Pliocene. Thus, as the cordilleras attained higher elevations in the Pliocene and Pleistocene, the ranges of proto-species of Gastrotheca (and other genera) became isolated and species differentiated allopatrically.

The anuran fauna is rich and diverse in the Andes of southern Ecuador and northern Peru and the intervening Huancabamba Depression. This is especially true of strabomantid (Craugastorid) frogs (Duellman and Lehr 2009, Lynch 1979). Ten species of strabomantids are known from elevations of 2400-3370 $\mathrm{m}$ in the northern part of the Cordillera Central (2 Hypodactyus, 1 Noblella, and 7 Pristimantis); nine of these are endemic to the region. Undoubtedly, the Cordillera Central in northern Peru contains many more species of anurans awaiting discovery, description, and phylogenetic placement. The high elevations of this cordillera have one of, if not, the richest anuran fauna in any high-elevation region in the Andes.

\section{Acknowledgments}

We are grateful to L.Y. Echevarría for preparing the map and to L. Trueb and two anonymous reviewers for their critical review of the manuscript. Venegas is indebted to A. García, L. Castro, M. Leo, and M. Salas for logistic support in the field. Expeditions in which specimens of Gastrotheca used in this paper were collected were funded by the simultaneous efforts of the non-governmental organizations, UCUMARI and Asociación Peruana para la Conservación de la Naturaleza (APECO), with the Gobierno Regional de Amazonas (GOREAM). Specimens of the new species and others reported in this paper were collected with the following permit 0581-2011-AG-DGFFSDGEFFS.

\section{References}

Barbour, T. and G. K. Noble. 1920. Amphibians and reptiles from southern Peru collected by the Peruvian expedition of 1914-1915 under the auspices of Yale University and the National Geographic Society. Proceedings of the United States National Museum 58: 608-620.

Blackburn, D. C. and W. E. Duellman. 2013. Brazilian marsupial frogs are diphyletic (Anura: Hemiphractidae: Gastrotheca). Molecular Phylogenetics and Evolution 68: 709-714.

Boulenger, G. A. 1900. Descriptions of new batrachians and reptiles collected by Mr. P. O. Simons in Peru. Annals and Magazine of Natural History 6: 181-186.

Carvajal-Endara, S., L. A. Coloma, M. A. Morales-Mite, J. M. Guayasamin, and W. E. Duellman. 2017. Phylogenetic systematics of marsupial frogs (Anura: Hemiphractidae) from the Andes of southern Ecuador with descriptions of three new biphasic species. Zootaxa (in revision).

Castroviejo-Fisher, S., J. M. Padial, I. De la Riva, J. P. Pombal Jr., H. R. Silva, F. J. H. Rojas-Runjiac, E. M. Méndez, and D. R. Frost. 2015. Phylogenetic systematics of egg-brooding frogs (Anura: Hemiphractidae) and the evolution of direct development. Zootaxa 4005: 1-75.

Dubois, A. 1987 (1986). Miscellanea taxinomica batrachologica (1). Alytes 5: 7-95.

Duellman, W. E. 1974. A systematic review of the marsupial frogs (Hylidae: Gastrotheca) of the Andes of Ecuador. Occasional Papers of the Museum of Natural History University of Kansas 22: 1-27.

Duellman, W. E. 1987. Two new species of marsupial frogs (Anura: Hylidae) from Peru. Copeia 1987: 903-909.

Duellman, W. E. 1999. Distribution patterns of amphibians in South America. Pp. 255-328 in W. E. Duellman (ed.), Patterns of Distribution of Amphibians: a Global Perspective. Baltimore and London: Johns Hopkins University Press. viii +633 pp.

Duellman, W. E. 2013. An elusive new species of marsupial frog (Anura: Hemiphractidae: Gastrotheca) from the Andes of northern Peru. Phyllomedusa 12: 3-11.

Duellman, W. E. 2015. Marsupial Frogs, Gastrotheca and Allied Genera. Baltimore and London: Johns Hopkins University Press. $\mathrm{xv}+407$ pp.

Duellman, W. E. and D. M. Hillis. 1987. Marsupial frogs (Anura: Hylidae: Gastrotheca) of the Ecuadorian Andes: resolution of taxonomic problems and phylogenetic relationships. Herpetologica 43: 141-173. 
Duellman, W. E. and E. Lehr. 2009. Terrestrial-breeding frogs (Strabomantidae) in Peru. Münster, Germany: Natur und Tier-Verlag. 382 pp.

Duellman, W. E. and L. Trueb. 1988. Cryptic species of hylid marsupial frogs in Peru. Journal of Herpetology 22: $159-179$.

Duellman, W. E. and P. Venegas. 2005. Marsupial frogs (Anura: Hylidae: Gastrotheca) from the Andes of northern Peru with descriptions of two new species. Herpetologica 61: 295-307.

Duellman, W. E. and E. R. Wild. 1993. Anuran amphibians from the Cordillera de Huancabamba, northern Peru: systematics, ecology, and biogeography. Occasional Papers of the Museum of Natural History University of Kansas 157: 1-53.

Duellman, W. E., A. J. Barley, and P. J. Venegas. 2014. Cryptic species diversity in marsupial frogs (Anura: Hemiphractidae: Gastrotheca) in the Andes of Northern Peru. Zootaxa 3768: 159-177.

Gregory-Wodzicki, K. M. 2000. Uplift history of the central and northern Andes: a review. Geological Society of America Bulletin 112: 1091-1105.
Lehr, E. and A. Catenazzi. 2011. A new species of marsupial frog (Anura: Hemiphractidae: Gastrotheca) from the Río Abiseo National Park in Peru. Herpetologica 67: 449-459.

Lynch, J. D. 1979. Leptodactylid frogs of the genus Eleutherodactylus from the Andes of Southern Ecuador. Miscellaneous Publications of the Museum of Natural History University of Kansas 66: 1-62.

Parker, H. W. 1932. Some new or rare reptiles and amphibians from southern Ecuador. Annals and Magazine of Natural History (10) 9: 21-26.

Sabaj Pérez, M. H. (ed.). 2010. Standard Symbolic Codes for Institutional Resource Collections in Herpetology and Ichthyology: an online reference. Available at http:// www.asih.org/node.

Trueb, L. and W. E. Duellman. 1978. An extraordinary new casque-headed marsupial frog (Hylidae: Gastrotheca). Copeia 1978: 498-503.

Editor: Jaime Bertoluci 
Appendix I. Comparative material examined.

Gastrotheca abdita. PERU: Amazonas: Cordillera Colán, 2970-3330 m, E La Peca, KU 96833 (holotype), $196834-35$. Gastrotheca aguaruna. PERU: Amazonas: Molinapampa, 2400 m, KU 212022 (holotype). 212023-28, 212030-31. Gastrotheca aratia. PERU: Cajamarca: Cutervo: KU 212060, 212062-66, 8 km NW Cutervo, KU 212067 (holotype). Gastrotheca dysprosita. PERU: Amazonas: west slope Abra Barro Negro, 3440 m, KU 212078 (holotype).

Gastrotheca excubitor, PERU: Cusco: N slope Abra Acjanaco, 3270-3520 m, KU 139193-201.

Gastrotheca galeata. PERU: Piura; 15 km (by road) E Canchaque, 1740-1890 m, KU 174361-63, 181700, $219765-66$. Gastrotheca griswoldi. PERU: Junín: Pacha, 9.5 km NW La Oroya, KU 139140-61.

Gastrotheca lateonota. PERU: Piura: El Tambo, 31.5 km E Canchaque, 2180 m, KU 181730-39.

Gastrotheca litonedis. ECUADOR: Azuay: 10 km NE Girón, 2750 m, KU 202690; (holotype); San Fernando, Laguna de Busa, 22834 m, KU 335388-89.

Gastrotheca lojana. ECUADOR: Azuay: Girón, 2310 m, KU 138401-03. Loja: Loja, 2150 m, KU 120673-74; 5 km N Loja, 2150 m. KU 138235-36; Saraguro, 2412 m, KU 138404-09; 2 km SSW Saraguro, 2569 m, KU $178482-95$.

Gastrotheca monticola. PERU: Piura: Huancabamba, 1960 m, KU 219771; 1.8 km N Huancabamba, 1980 m, KU 21976768; 4 km N Huancabamba, 1900 m, KU 219769-70.

Gastrotheca nebulanastes. PERU: Cusco: Buenos Aires, 2280 m, KU 123208-09, 123210 (holotype), 123211-17.

Gastrotheca ochoai. PERU: Cusco: Chilca, 10 km N Ollantaytambo, 2760 m, KU 138628-65.

Gastrotheca ossilaginis. PERU: San Martín: Lago Quindecocha, 3100 M, KU 117293.

Gastrotheca pacchamama. PERU: Ayacucho: Abra Tapuna, 7 km N Mahuayara, 3710 m, KU 163279-99.

Gastrotheca pachachacae. PERU: Apurimac: Ccerabamba-Andina Chinchay cloud forest, 30050 m, MUSM $18489-92$.

Gastrotheca peruana. PERU: Cajamarca: 8 km S Cajamarca, 3050 m, KU 212070; Cutervo, 2620 m, KU 212055-57, 212060-66.

Gastrotheca phalarosa. PERU: San Martín: Esperanza, 3435 m, MUSM 19462, 19487 (holotype).

Gastrotheca phelloderma. PERU: Amazonas: Hornillo, 3308 m, CORBIDI 11778. San Martín: 24 km NE Pataz, 3400 m. KU 331039-40.

Gastrotheca pseustes. ECUADOR: Saraguro, 2500 m, KU 141571, 142609-13, 148563-67.

Gastrotheca psychrophila. ECUADOR: Loja-Zamora-Chinchipe: 13-15 km E Loja, 2770-2850 m, KU 120760 (holotype), 120761-62, 141586, 142631-37, 148599, 164233-34.

Gastrotheca rebeccae. PERU: Ayacucho: Ccarpa, below Tambo on Valle de Apurimac trail, 2470 m. LU 196806-11.

Gastrotheca sp. A. ECUADOR: Azuay: Cuenca, 2600 m, KU 120672, 120683-84, 120709-10, 120718-19, 120721-22; Laguna de Zurucuchu, 3200 m, KU 203441.

Gastrotheca sp. B. ECUADOR: Loja: 5.2 km W Loja, 2310 m, KU 202688; 5.5 km W Loja, 2330 m, KU 142603-08, 148549-51.

Gastrotheca sp. D. ECUADOR: Loja: Laguna de Jimbura, Parque Nacional Yacuri, Amaluza, 3406 m, KU 335390.

Appendix II. Specimens used in phylogenetic analysis with associated GenBank numbers.

\begin{tabular}{lccccc}
\hline Species & Voucher Number & ND1 & 16s & POMC & RAG1 \\
\hline Gastrotheca oresbios & CORBIDI 11040 & KJ489508 & KJ489460 & - & KJ489507 \\
Gastrotheca oresbios & CORBIDI 11076 & KJ489509 & KJ489461 & KJ489552 & KJ489588 \\
Gastrotheca spectabilis & CORBIDI 11790 & KJ489513 & KJ489464 & KJ489554 & KJ489592 \\
\hline
\end{tabular}

